Santos Almeida Ribeiro, Maristela.

Artista-investigadora e Profesora de Arte do Instituto Federal da Bahía-

Feira de Santana - Bahía-Brasil.

\title{
Paisajes Expandidas entre Brasil y España: intervenciones fotográficas introducidas en el espacio público.
}

\section{Extended Landscapes between Brasil and Spain: photograph interventions on the public space.}

TIPO DE TRABAJO:

Comunicación.

PALABRAS CLAVE:

Arte contemporáneo, fotografía, intervención artística, espacio público, arte urbano.

KEY WORDS:

Contemporary art, photography, artistic intervention, public space, urban art.

RESUMEN .

Este artículo propone una reflexión acerca de los métodos de creación de la imagen desde dos proyectos artísticos: el primero consiste en una serie de trabajos desarrollados en Feira de Santana y Salvador de Bahía, en el Nordeste de Brasil; y el segundo en otra serie que tuvo lugar en los barrios de Benimaclet y Cabanyal, con sede en Valencia, en la costa mediterránea de España, durante una Estancia Doctoral en la Escuela de Bellas Artes de la Universidad Politécnica de Valencia. Estos dos "lugares" - en Brasil y España - forman pilares importantes para que se pueda suponer, inferir y analizar los resultados. Los dos experimentos son esenciales en la orientación de la obra en su conjunto, con la delimitación de un corpus epistemológico y la definición de los procedimientos adoptados en su naturaleza y validez.

Para desarrollar la investigación contenida en estos proyectos, la metodología adoptada buscó apoyo en la ciencia y la filosofía de la creación que, según Passeron tiene como objeto la realización creativa. El recorte adoptado enfoca el desplazamiento de la imagen fotográfica del ámbito privado al público, introducida en el espacio urbano cómo intervenciones artísticas, en formatos grandes.

La redefinición del espacio, a través de la imagen fotográfica, se constituye desde la carga semántica de las imágenes desplazadas; toma la arquitectura como lugar, la calle como un espacio para una experiencia artística y la ciudad como un campo poético. Por lo tanto, la experiencia artística sugiere diferentes maneras de hablar de un lugar en particular, su cultura, su entorno y su historia, a través de imágenes que se han desviado de sus contextos originales. 


\section{ABSTRACT.}

This article proposes a reflection about the methods of creation of the image from two artistic projects: the first one consists of a series of works developed in Feira de Santana and Salvador de Bahía, in the Northeast of Brazil; And the second in another series that took place in the districts of Benimaclet and Cabanyal, based in Valencia, on the Mediterranean coast of Spain, during a Doctoral Stay at the School of Fine Arts of the Polytechnic University of Valencia. These two "places" - in Brazil and Spain - form important pillars so that results can be assumed, inferred and analyzed. The two experiments are essential in the orientation of the work as a whole, with the delimitation of an epistemological corpus and the definition of the procedures adopted in their nature and validity.

To develop the research contained in these projects, the methodology adopted sought support in science and the philosophy of creation that, according to Passeron aims at creative realization. The adopted approach focuses on the displacement of the photographic image from the private to the public, introduced in the urban space as artistic interventions, in large formats.

The redefinition of space, through the photographic image, is constituted from the semantic load of the displaced images; Takes the architecture as a place, the street as a space for an artistic experience and the city as a poetic field. Therefore, artistic experience suggests different ways of talking about a particular place, its culture, its environment and its history, through images that have deviated from their original contexts. 